\title{
Characterization, antioxidant potential and cytotoxic study of mangaba fruits
}

\author{
Caracterização, potencial antioxidante e estudo citotóxico de frutos de mangaba
}

\author{
Carolina Fagundes Assumpção ${ }^{\mathrm{I}}$ Patrícia Bachiega $^{\mathrm{II}}$ Maressa Caldeira Morzelle ${ }^{\mathrm{II}}$ \\ David Lee Nelson ${ }^{\mathrm{III}}$ Eliane Augusto Ndiaye ${ }^{\mathrm{IV}}$ Alessandro de Oliveira Rios ${ }^{\mathrm{I}^{*}}$ \\ Éllen Cristina de Souzav
}

\section{ABSTRACT}

The mangaba (Hancornia speciosa) stands out and has a great potential for economic exploitation and researches have suggested relevant results regarding the nutritional and functional value of this food. Therefore, the objective of this study was to chemically and physicochemically characterize the mangaba fruit harvested in the Middle Araguaia region. It was evaluated the chemical composition, antioxidant activity, volatile compounds, preliminary photochemical studies of phenolic components and the cytotoxic potential of ethanolic extract fruits against Artemia salina. The mean $\mathrm{pH}$, the total titratable acidity and the value for reducing sugars conclude that the mangaba possesses the characteristics appropriate for both fresh consumption and for processing. Between the mean values measured, the fruits presented high fiber content and a low caloric value. The analysis of the antioxidant potential revealed a significant activity and in the volatile compounds analysis, esters were the major class presents. The result of the phytochemical screening revealed that phenols, flavonoids and tannins were present in the ethanolic extract of mangaba and a significant activity in the cytotoxicity assay was observed.

Key words: Hancornia speciosa, antioxidante activity, phytochemical study.

\section{RESUMO}

A mangaba (Hancornia speciosa) destaca-se pelo ótimo potencial de exploração econômica e pesquisas têm sugerido resultados relevantes em relação ao valor nutricional e funcional deste alimento. Portanto, o objetivo deste estudo foi caracterizar química e físico-quimicamente os frutos de mangaba colhidos na região do Médio Araguaia. Foi avaliada a composição química, atividade antioxidante, compostos voláteis, estudo fitoquímico preliminar de compostos fenólicos e o potencial citotóxico de extratos etanólicos do frutos contra Artemia salina. O pH, a acidez total titulável e o valor de açúcares redutores concluem que a mangaba possui características apropriadas tanto para consumo in natura quanto para processamento. Entre os valores médios obtidos, os frutos apresentaram alto teor de fibra e um baixo valor calórico. A análise de potencial antioxidante revelou uma atividade significativa e, na análise de compostos voláteis, ésteres representaram a classe predominante. O resultado do ensaio fitoquímico revelou que fenois, flavonoides e taninos estavam presentes no extrato etanólico de mangaba e uma atividade significativa no ensaio citotóxico foi observada.

Palavras-chave: Hancornia speciosa, atividade antioxidante, ensaio fitoquímico.

\section{INTRODUCTION}

Studying the relationship between current lifestyles and the consumption of functional foods, SZAKALY et al. (2012), suggested that most classes of consumers opt for functional foods, making consciously decisions . According to their studies, there is a close relationship between lifestyle, behavior and health and the preference for functional foods. This study brings to light the magnitude of the current functional food market, where the population is already able to identify which foods are best for their own consumption.

In this sense, Brazil possesses a large number of native fruits that have recently been

${ }^{\mathrm{I}}$ Ciência dos Alimentos, Universidade Federal do Rio Grande do Sul (UFRGS), Av. Bento Gonçalves, Campus do Vale, Prédio 43.212, 9500, 91501-970, Porto Alegre, RS, Brasil. E-mail: alessandro.rios@ufrgs.br.*Autor para correspondência.

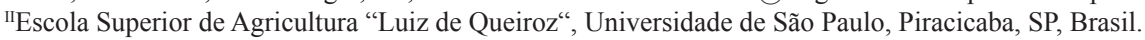

IIIUniversidade Federal de Minas Gerais, Belo Horizonte, MG, Brasil.

${ }^{\mathrm{IV}}$ Instituto de Ciências Biológicas e da Saúde, Universidade Federal de Mato Grosso, Pontal do Araguaia, MT, Brasil.

VInstituto de Ciências Exatas e da Terra, Universidade Federal de mato Grosso, Pontal do Araguaia, MT, Brasil. 
discovered to be functional. Among these fruits, the mangaba (Hancornia speciosa), a tropical fruit belonging to the Apocinaceas family, stands out and has a great potential for economic exploitation, as it is still consumed fresh and there are few manufactured products developed based on this fruit.

SERRA et al. (2005) showed that the ethanol extract of mangaba leaves exerts a hypotensive effect by inhibiting the angiotensinconverting enzyme (ACE), and FERREIRA et al. (2007 a, b) demonstrated that this extract induces vasodilation through the production of nitric oxide, which is involved in the modulation of gastric mucosal integrity by adjusting the alkaline and acid secretions and the blood flow in the gastric mucosa. MORAES et al. (2008) suggested in their studies that the effectiveness of mangaba in fighting and healing gastric ulcers is based on its ability to stimulate the synthesis of mucus, causing an anti-secretory effect and exerting an anti-Helicobacter pylori action without toxic effects.

In this sense, many plants are known to be toxic and that the evaluation of the toxic action of its extracts is essential for its use can be considered safe. Toxic substances can actually display, in nontoxic doses, interesting pharmacological effects such as the case with safrole, which despite its proven carcinogenic activity, it is precursor of several drugs, such as, for example, antithrombotic drugs.

One of the analyzes to detect toxic substances use Artemia salina, which is an invertebrate fauna component of the marine ecosystem, a microcrustacean whose larvae are sensitive to a variety of substances. The bioassay using Artemia salina also has the advantage of being a simple test to predict the toxicity of plant extracts, guide their phytochemical fractionation, besides being quick, inexpensive allowing for a large number of samples to be tested and processed appropriately.

Being a little-known exotic fruit, studies on the mangaba in midwest Brazil are of great importance, since research has suggested relevant results regarding the nutritional and functional value of this food. Therefore, the objective of this study was to chemically and physicochemically characterize the mangaba fruit harvested in the Middle Araguaia region.

\section{MATERIAL AND METHODS}

Fruit harvesting and sample preparation

The fruits of the mangaba (Hancornia speciosa) were acquired in 2009 during the harvesting period (October to November) from the producers of the Middle Araguaia, which includes the towns of Barra do Garças (MT); Pontal do Araguaia (MT) and Aragarças (GO).

\section{Chemical composition}

The analyses of chemical composition (protein, lipid, moisture, fiber (total and insoluble, ash, carbohydrate, reducing and non-reducing sugars, total titratable acidity (TTA), total soluble solids (TSS), $\mathrm{pH}$ and total energy) were performed according to AOAC, 1997.

\section{Antioxidant activity}

A methodology based on sequestering the 2,2-diphenyl-1-picrylhydrazyl (DPPH) radical was used to determine the antioxidant activity (BRANDWILLIAMS et al., 1995). The extract was obtained from $5 \mathrm{~g}$ of sample ground in 50\% methanol and 70\% acetone using different dilutions. The fresh samples were weighed in centrifuge tubes and extracted sequentially with $40 \mathrm{~mL}$ of $50 \%$ methanol at room temperature for $60 \mathrm{~min}$. The tubes were centrifuged at $25400 \mathrm{~g}$ for $15 \mathrm{~min}$, and the supernatant was recovered. An aliquot of $40 \mathrm{~mL}$ of $70 \%$ acetone was then added to the residue at room temperature, extracted for $60 \mathrm{~min}$, and centrifuged. The methanol and acetone extracts were combined, made up to $100 \mathrm{~mL}$ with distilled water, and used to determine the antioxidant capacity. For the DPPH method, a $0.1 \mathrm{~mL}$ aliquot of each dilution of the extract was treated with $3.9 \mathrm{~mL}$ of DPPH radical. The readings were performed in a spectrophotometer at $515 \mathrm{~nm}$ after $30 \mathrm{~min}$. The results are expressed as the concentration of antioxidant required to reduce the original amount of free radicals by $50 \%$ (EC50), and the values are expressed as $g$ of fruit $\mathrm{g}^{-1} \mathrm{DPPH}$.

\section{Volatile compounds}

The extraction and identification of volatile compounds were performed using the technique of solid phase microextraction (SPME) using a gas chromatograph coupled to a mass spectrometer - a Shimadzu GC 2010 Gas Chromatograph and a QP2010 Plus Gas Chromatograph-Mass Espectrometer. The samples were prepared by headspace to analyze the volatiles according to XISTO (2012).

A gas chromatograph with a mass selective detector was employed for the identification of the volatile components using a: $30 \mathrm{~m} \times 0.25 \mathrm{~mm}$ and $0.25 \mu \mathrm{m}$ fused silica capillary column, $5 \%$ diphenyl and $95 \%$ polydimethylsiloxane (DB5) stationary phase. The injector temperature was $270^{\circ} \mathrm{C}$; the column temperature was programmed with an initial temperature of $35^{\circ} \mathrm{C}$ and an increase of $3^{\circ} \mathrm{C}$ per 
minute until reaching $270^{\circ} \mathrm{C}$. The carrier gas was helium with a flow rate of $1.78 \mathrm{~mL} \mathrm{~min}^{-1}$ in the split mode and an initial column pressure of $120.9 \mathrm{kPa}$. A mass selective detector operating in electron impact mode with an impact energy of $70 \mathrm{eV}$ was used. The scan speed was $1000 \mathrm{~m} \mathrm{z}^{-1} \mathrm{~s}^{-1}$. The scan interval was 0.5 fragments second ${ }^{-1}$ and fragments between 29Da and 600Da were detected. The identification of volatile compounds was performed by comparing their mass spectra with the measured spectra database (Wiley and 8.LIB FFNSC.1.2.lib).

Preliminary phytochemical studies of phenolic components

The experiment for characterization of the different phenolic constituents in the ethanolic extract of the mangaba was based on the method described previously (MATOS, 1988).

Cytotoxic potential of ethanolic extracts against Artemia salina

The modified method of UTYAMA (2003) was used to determine the inhibitory activity of the extracts on Artemia salina in vial bottles. Brine shrimp (A. salina) were hatched using brine shrimp eggs in a plastic vessel $(500 \mathrm{~mL})$ filled with sterile artificial sea water (Prepared using $\mathrm{NaCl}$ salt $\left(38 \mathrm{~g} \mathrm{~L}^{-1}\right)$ and adjusted to $\mathrm{pH} 8.5$ using $40 \% \mathrm{NaOH}$, with constant aeration for $48 \mathrm{~h}$. After hatching, active nauplii free from egg shells were harvested from the brighter portion of the hatching chamber and used for the assay. Ten nauplii were drawn through a glass capillary and placed in each vial containing $5 \mathrm{~mL}$ of brine solution. Portions of different concentrations of crude ethanolic extract $\left(300,275,250,225,200,175,150\right.$, and $\left.100 \mu \mathrm{g} \mathrm{mL}^{-1}\right)$ solution in $1 \%$ DMSO-artificial sea water was added to each well (vial bottle) containing 10 newly-hatched brine shrimp and then incubated at room temperature for $24 \mathrm{~h}$. The experiment was run in triplicate at each concentration. The number of dead and surviving brine shrimp in each tube was counted after $24 \mathrm{~h}$. To ensure that the mortality observed in the bioassay is related to bioactive compounds, the number of dead larvae in each treatment was compared to the number of dead larvae in the control. According to MEYER et al. (1982), lethal doses $\left(\mathrm{LD}_{50}\right)$ below $10^{3} \mu \mathrm{g} \mathrm{mL}^{-1}$ indicate cytotoxicity. The $50 \%$ lethal dose $\left(\mathrm{LD}_{50}\right)$ was calculated using Probit analysis with 95\% of confidence intervals.

\section{RESULTS AND DISCUSSION}

The mean $\mathrm{pH}$ of the mangaba fruit was $2.82 \pm 0.03$. The total titratable acidity (TTA) in the mangaba, expressed as a citric acid, was found to be $2.01 \pm 0.38 \%$. The TTA results signify that the mangaba possesses the characteristics appropriate for both fresh consumption and for processing. Regarding the market for table fruit, this fruit has a very distinguished flavor and, as for processing, the low $\mathrm{pH}$ signifies lower costs for processing, since the addition of acidulants to reduce the $\mathrm{pH}$ is not required. A pH above 4.5 can enhance growth of Clostridium bolutinum, a pathogenic anaerobic bacteria that causes botulism.

The mean soluble solids (SS) of the mangaba fruit was $13.06 \pm 0.01^{\circ} \mathrm{Brix}$, which are above the recommended range for fruit destined for processing, providing more natural taste to the mangaba fruits of the Middle Araguaia. Thus, the fruits from the Middle Araguaia region are more important in the production context. From a business standpoint, fruits with higher soluble solids levels are preferred both for fresh consumption and for industrial processing (PEREIRA et al., 2000); thus, the use of mangaba is favorable. The SS/TTA ratio of these fruits was 6.5.

The mean value found for reducing sugars was $9 \pm 0.52 \%$. The content of soluble sugars increases with the ripening of the fruit through biosynthesis processes or degradation of polysaccharides. The mean values measured in the analyses of the nutritional value of the mangaba fruit are presented in table 1 .

Studying 10 different clones of mangabeiras from Northeast region, SOUZA et al. (2007) reported values close to this research, but with higher values for SS, thereby generating higher values for SS/ TTA relation. These differences can be explained by different methods or by the plant growing site.

The analysis of the antioxidant potential of the mangaba fruit revealed an EC50 equal to $3050 \mathrm{~g}$ of fruit $\mathrm{g}^{-1}$ of DPPH, a value that is similar to that found by RUFINO et al. (2010) in the analysis of mangaba fruit from the Northeast region of the country. The

Table 1 - Chemical composition of mangaba fruit (Hancornia speciosa).

\begin{tabular}{lc}
\hline Component & Composition (\%) \\
\hline Moisture $\left(\mathrm{g} 100 \mathrm{~g}^{-1}\right.$ fresh matter) & $83.3 \pm 0.20$ \\
Lipid $\left(\mathrm{g} 100 \mathrm{~g}^{-1}\right.$ fresh matter) & $2.30 \pm 0.06$ \\
Protein $\left(\mathrm{g} 100 \mathrm{~g}^{-1}\right.$ fresh matter) & $0.86 \pm 0.03$ \\
Fiber $\left(\mathrm{g} 100 \mathrm{~g}^{-1}\right.$ fresh matter) & $4.50 \pm 0,01$ \\
Carbohydrate (g100 $\mathrm{g}^{-1}$ fresh matter) & $8.61 \pm 0,01$ \\
Ash (g $100 \mathrm{~g}^{-1}$ fresh matter) & $0.43 \pm 0.01$ \\
Caloric value (kcal $\left.100 \mathrm{~g}^{-1}\right)$ & 58.58 \\
\hline
\end{tabular}


capacity for reduction of the DPPH radicals was determined by the decrease in absorbance, which is induced by the antioxidants present in the material studied. The results indicate that mangaba fruit have the ability to scavenge free radicals. It is suggested that this activity can be attributed to the phenolic compounds present in the fruit. The antioxidant activity of the polyphenols is justified mainly by their reducing properties. The intensity of the antioxidant exhibited by these phytochemicals is differentiated, since it depends on the number and position of hydroxyl groups present in the molecule (RICEEVANS et al., 1996).

The identified volatile compounds corresponded to $83.72 \%$ of the total area of the peaks (Table 2). Among these compounds, the classes identified in order of decreasing prevalence were esters (six compounds), aldehydes (three compounds), alcohols (three compounds), hydrocarbons (two compounds) and ketone (one compound). Esters represented $68.11 \%$ of the total area of the peaks, the major class of compounds present in the mangaba fruit.

SAMPAIO \& NOGUEIRA (2005) reported that esters were the predominant compounds in ripe mangaba fruit when analyzed by the same technique of GC-MS. Brazil has a natural diversity of fruits. Many are considered to be exotic because they have different aromas and flavors. This huge diversity of fruits represents a promising area for research on aromas because of their unusual sensory properties and the possibility of increasing the interest of consumers worldwide in fruits that have only regional importance, such as mangaba.

In this sense, the profile of volatile compounds in mangaba is a valuable information since it can be used to develop new flavors with high applicability for cosmetics and food. Moreover, the fruits are edible, and the mixture of volatile compounds gives origin to a peculiar flavor that can be better exploited by the food industry.

Epidemiologic and dietary studies recognize that there are many naturally occurring bioactive compounds called phytochemicals that can confer significant long-term health benefits (AGUILERA et al., 2011), between them, phenolic compounds are widely distributed in plants and have recently gained much attention due to their antioxidant activity and free radical scavenging ability (HERNÁNDEZ et al., 2011).

Hancornia speciosa is traditionally used in the treatment of several diseases, including hypertension and inflammatory diseases, mainly dermatites, rheumatism and hepatitis (SERRA et al., 2005; AGRA et al., 2007; BRANDÃO et al., 2011). The result of the phytochemical screening (Table 3) revealed that phenols, flavonoids and tannins were present in the ethanolic extract of $\boldsymbol{H}$. speciosa. Alkaloids and coumarins were absent in this extract. The pronounced presence of flavonoids and tannins in this extract may be responsible for its use in the

Table 2 - Retention times, the mean percentage of the areas under the peaks and volatile compounds identified in mangaba fruits analyzed by SPME-GC/MS (Solid Phase Microextraction-Gas Chromatography/Mass Espectrometer).

\begin{tabular}{lcll}
\hline Retention Time (min) & Area (\%) & \multicolumn{1}{c}{ Compound } & Classification \\
\hline 6.77 & 1.01 & 3-methyl-2-butenol & Alcohol \\
7.01 & 1.95 & 3-methyl-2-butenol & Alcohol \\
7.46 & 5.24 & Hexanal & Aldeído \\
7.64 & 1.41 & Ethyl butanoate & Ester \\
10.17 & 2.31 & 2-hexenal & Aldehyde \\
11.47 & 28.62 & Isopentyl acetate & Ester \\
11.96 & 23.44 & 4-isopentyl acetate & Ester \\
14.40 & 5.52 & 3-methyl-2-butenyl acetate & Ester \\
19.53 & 8.89 & Ethyl hexanoatea & Ester \\
20.64 & 3.89 & Bicyclo [2.2.0] hexane-1-carbaldeíde & Aldehyde \\
39.85 & 0.12 & Not identified & -- \\
43.63 & 0.54 & Dimethylundecane & Hydrocarbon \\
43.72 & 0.27 & 3-methoxy-3-methyl-2-butanone & Ketone \\
44.19 & 0.23 & Methyl 1,2-dimethyltetradecanoate & Ester \\
44.46 & 0.22 & Dihexylsulfidric & -- \\
45.44 & 15.94 & Not identified & -- \\
46.82 & 0.08 & 2-propyldecanol & Alcohol \\
47.18 & 0.32 & 3,3-dimethylhexane & Hydrocarbon \\
\hline
\end{tabular}


Table 3 - Qualitative analysis of the phytochemical components of $\boldsymbol{H}$. speciosa.

\begin{tabular}{lc}
\hline Phytochemical components & Presence in ethanol extract \\
\hline $\begin{array}{l}\text { Phenols and tannins } \\
\text { Anthocyanins, anthocyanidins } \\
\text { and flavonoids }\end{array}$ & ++ (condensed tannins) \\
$\begin{array}{l}\text { Flavones, flavonols and } \\
\text { xanthones }\end{array}$ & ++ \\
$\begin{array}{l}\text { Leucoanthocyanidins, } \\
\text { catechins and flavonones } \\
\text { Flavonols, flavanones, } \\
\text { flavononols and xanthones } \\
\text { Catechins confirmation }\end{array}$ & ++ (flavonones) \\
$\begin{array}{l}\text { Alkaloids } \\
\text { Coumarins }\end{array}$ & 0 \\
\hline
\end{tabular}

Presence (++ or +$)$; Absence (-); Not determined (0).

treatment of chronic inflammatory problems and is an indication that the investigation of the antiinflammatory activity of this species can generate promising results. Further studies are being performed on this plant to isolate, identify, characterize and elucidate the structures of the bioactive compounds. A significant activity in the brine shrimp cytotoxicity assay was observed for the ethanol extract of $\boldsymbol{H}$. speciosa. The $\mathrm{LD}_{50}$ was $219.2 \pm 2.3 \mu \mathrm{g} \mathrm{mL}^{-1}$ (Figure 1). Investigating specific tumors (colon carcinoma, melanoma, glioblastoma and leukemia promielocitic), RIBEIRO et al. (2012) reported that mangaba would not be active. This does not mean that the extract of mangaba is also inactive for other/ all forms of tumor. While RIBEIRO et al. (2012) used leaves, branches, fruit and latex, this study used the whole mature. Furthermore, the process of extraction and concentration used were different, which may have affected the concentration of active substances.

The toxicity presented by some drugs is a frequent reason for their removal from the therapeutic arsenal. Thus, besides the toxic activity, several studies tried to correlate the toxicity on Artemia salina with activities such as antifungal, antibacterial, parasiticide, trypanocidal, among others. Paradoxically, in the search for preventive compounds, some samples can be selected for study on the basis of their cytotoxic and antiproliferative activities. Chemoprevention with functional food emerges as an important strategy for cancer prevention and control, suggesting mechanisms of anti-carcinogenic, anti-oxidant, anti-inflammatory, anti-hormonal, anti-angiogenic spectra among others, although scientific evidence is controversial and weakly supported by epidemiological studies.

The presence of secondary metabolites, flavonoids and tannins, can be related to the action of the $\boldsymbol{H}$. speciosa fruit extract in certain pathological disturbances. The phytochemicals in the diet responsible for the chemoprevention has been discussed (KUCUK, 2002). The most widely studied cancer preventive food compounds are phytochemicals. Research should be stimulated, considering the fact that it is necessary to know more about these food substances.

\section{CONCLUSION}

The present study indicated that the mangaba fruit has the appropriate characteristics for both fresh consumptions and for processing due to its values of $\mathrm{pH}$, titratable acidity, soluble solids,

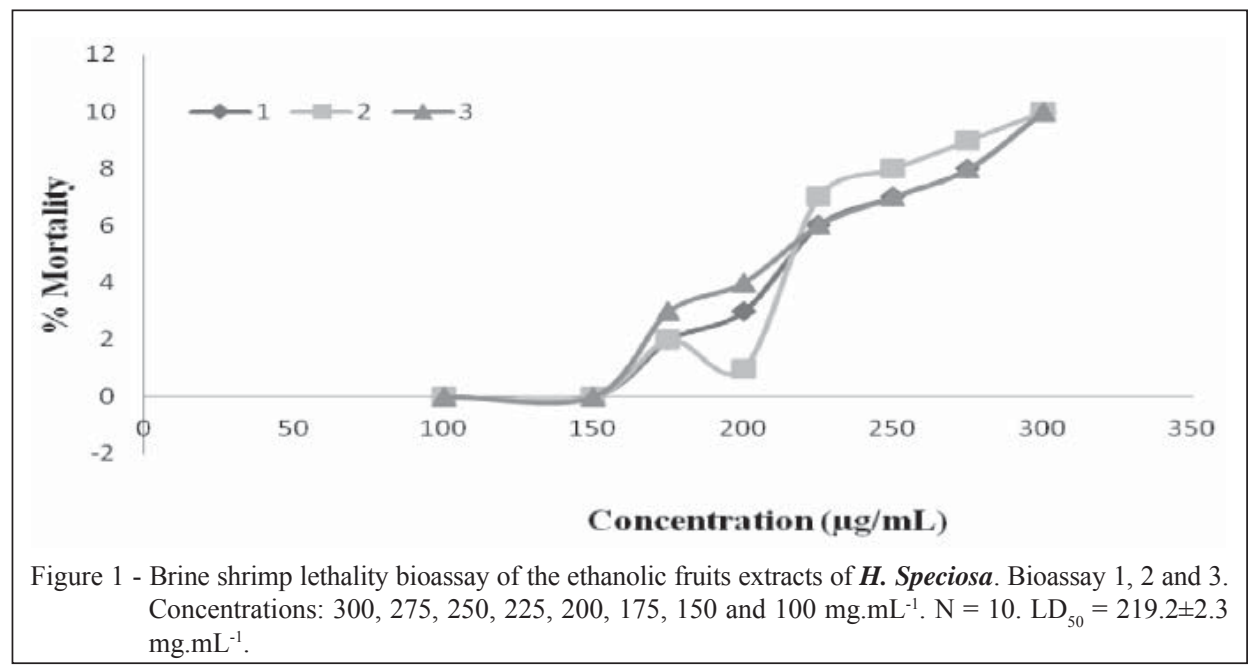

Ciência Rural, v.44, n.7, jul, 2014. 
reducing sugars and high fiber content. The analysis of the antioxidant potential revealed that mangaba fruit have the ability to scavenge free radicals, suggesting that this activity can be attributed to the phenolic compounds present in the fruit. In the volatile compounds analysis, esters were the major class. Flavonoids, phenols and tannins were present in the ethanolic extract of mangaba and a significant activity in the brine shrimp cytotoxicity assay was observed.

\section{REFERENCES}

AGRA, M.F. et al. Synopsis of the plants known as medicinal and poisonous in Northeast of Brazil. Revista Brasileira de Farmacognosia, v.17, n. 1, p.114-140, 2007. Available from: http://www.scielo.br/scielo.php?script=sci_arttext\&pid=S0102695X2007000100021>. Accessed: Oct. 10, 2011. doi: 10.1590/ S0102-695X2007000100021.

AGUILERA, Y. et al. Phenolic profile and antioxidant capacity of chickpeas (Cicer arietinum L.) as affected by a dehydration process. Plant Foods for Human Nutrition, v.66, n.2, p.187-195, 2001. Available from: <http://link.springer.com/ article/10.1007\%2Fs11130-011-0230-8\#page-1>. Accessed: Oct. 10, 2011. doi: 10.1007/s11130-011-0230-8.

AOAC. Official methods of analysis of the Association of the Agricultural Chemists. 16.ed. Gaithersburg, 1997. 1298p.

BRANDÃO, G.C. et al. Antiviral activity of plants occurring in the State of Minas Gerais (Brazil): Part III. Journal of Chemical and Pharmaceutical Research, v.3, n.4, p.223-236, 2011. Available from: <http://jocpr.com/vol3-iss4-2011/JCPR-2011-3-4-223-236. pdf $>$. Accessed: Dec. 03, 2011.

BRAND-WILLIAMS, W. et al. Use of a free radical method to evaluate antioxidant activity. Food Science and Technology, v.28, n.1, p.25-30, 1995. Available from: <http://www.sciencedirect. com/science/article/pii/S0023643895800085>. Accessed: Oct. 10, 2011. doi: 10.1016/S0023-6438(95)80008-5.

FERREIRA, H.C. et al. Endothelium-dependent vasodilatation induced by Hancornia speciosa in rat superiormesenteric artery. Phytomedicine, v.14, n.7-8, p.473-478, 2007a. Available from: $<$ http:// www.sciencedirect.com/science/article/pii/S0944711306001711>. Accessed: Oct. 10, 2011. doi: 10.1016/j.phymed.2006.11.008.

FERREIRA, H.C. et al. Nitric oxide-dependent vasodilatation by ethanolic extract of Hancornia speciosa via phosphatidyl-inositol3-kinase. Journal of Ethnopharmacology, v.109, n.1, p.161-164, 2007b. Available from: <http://www.sciencedirect.com/science/ article/pii/S0378874106003229>. Accessed: Oct. 10, 2011. doi: 10.1016/j.jep.2006.06.009.

HERNÁNDEZ, L. et al. Phenolic compounds in wheat grain cultivars. Plant Foods for Human Nutrition, v.66, n.4, p.408415, 2011. Available from: <http://link.springer.com/article/10. 1007\%2Fs11130-011-0261-1>. Accessed: Dec. 03, 2011. doi: 10.1007/s11130-011-0261-1.

KUCUK, O. New opportunities in chemoprevention. Cancer Investigation, v.20, n.2, p.237-45, 2002. Available from: <http:// web.ebscohost.com/ehost/detail? sid=2b9d1e74-6595-45c5- be59-625a5d421bbb\%40sessionmgr198\&vid=1\&hid=128\&bd $\mathrm{ata}=$ Jmxhbmc9cHQtYnImc210ZT1laG9zdC1 saXZ1\#db=mdc\& $\mathrm{AN}=11901544>$. Accessed: Oct. 10, 2011.

MATOS, F.J.A. Introdução à fitoquímica experimental. Fortaleza: EUFC, 1988. 150p.

MEYER, B.N. et al. Brine Shrimp: A Convenient General Bioassay for Active Plant Constituents. Journal of Medicinal Plant Research, v.45, p.31-34, 1982. Available from: <http://www.ncbi. nlm.nih.gov/pubmed/17396775>. Accessed: Oct. 11, 2011. doi: $10.1055 / \mathrm{s}-2007-971236$.

MORAES, T. de M. et al. Hancornia speciosa: indications of gastroprotective, healing and anti-Helicobacter pylori actions. Journal of Ethnopharmacology, v.120, n.2, p.161-168, 2008. Available in: <http://www-sciencedirect-com.ez45.periodicos. capes.gov.br/science/article/pii/S0378874108004273>. Accessed: Oct. 10, 2011. doi: 10.1016/j.jep.2008.08.001.

PEREIRA, M.C.T. et al. Atributos físicos e químicos de frutos de oito clones de jabuticabeiras. Revista Brasileira de Fruticultura, v. 22, p. $16-21,2000$.

RICE-EVANS, C.A. et al. Structure antioxidant activity relationship of flavonoids and phenolic acid. Free Radical Biology Medicine, v.20, n.7, p.933-956, 1996. Available from: <http:// www.sciencedirect.com/science/article/pii/0891584995022279>. Accessed: Oct. 10, 2011. doi: 10.1016/0891-5849(95)02227-9.

RIBEIRO, S.S. et al. Evaluation of the cytotoxic activity of some Brazilian medicinal plants. Planta Medica, v.78, n.14, p.16011606, 2012. Available from: <https://www.thieme-connect.de/ ejournals/abstract/10.1055/s-0032-1315043>. Accessed: Oct. 23, 2013. doi: $10.1055 / \mathrm{s}-0032-1315043$.

RUFINO, M.S.M. et al. Bioactive compounds and antioxidant capacities of 18 non-traditional tropical fruits from Brazil. Food Chemistry, v.121, p.996-1002, 2010. Available from:<http://www.sciencedirect.com/science/article/pii/ S0308814610001172>. Accessed: Oct. 13, 2013. doi: 10.1016/j. foodchem.2010.01.037.

SAMPAIO, T.S. et al. Volatile components of mangaba fuit (Hancornia speciosa) at three stages of maturity. Food Chemistry, v.95, n.4, p.606-610, 2005. Available from: <http:// www.sciencedirect.com/science/article/pii/S0308814605001287>. Accessed: Oct. 10, 2011. doi: 10.1016/j.foodchem.2005.01.038.

SERRA, C.P. et al. Validation of a colorimetric assay for the in vitro screening of inhibitors of angiotensin-converting enzyme (ACE) from plant extracts. Phytomedicine, v.12, n.6-7, p.424-432, 2005. Available from: $<$ http://www.sciencedirect.com/science/article/pii/ S0944711305000590>. Accessed: Oct. 10, 2011. doi: 10.1016/j. phymed.2004.07.002.

SOUZA, F.G. et al. Qualidade pós-colheita de frutos de diferentes clones de mangabeira (Hancornia speciosa Gomes). Ciência e Agrotecnologia, v.31, n.5, p.1449-1454, 2007. Available from: <http://www.scielo.br/scielo.php?pid=S1413$70542007000500027 \&$ script $=$ sci_arttext $>$. Accessed: Oct. 14, 2013. doi: $10.1590 / \mathrm{S} 1413-70542007000500027$. 
SZAKALY, Z. et al. The influence of lifestyle on health behavior and preference for functional food. Appetite, v.58, n.1, p.406-413, 2012. Available from: <http://www.sciencedirect.com/science/ article/pii/S0195666311006325>. Accessed: Dec. 03, 2012. doi: 10.1016/j.appet.2011.11.003.

UTYAMA, I.K.A. Avaliação da atividade antimicrobiana e citotóxica in vitro do vinagre e ácido acético: perspectiva na terapêutica de feridas. 2003. 148f. Dissertação (Mestrado em
Enfermagem Fundamental) - Escola de Enfermagem de Ribeirão Preto, Universidade de São Paulo, SP.

XISTO, A. L. R. P. et al. Volatile profile and physical, chemical, and biochemical changes in fresh cut watermelon during storage. Ciência e Tecnologia de Alimentos, v.32, p.173-178, 2012. Available from: <http://www.scielo.br/scielo.php?pid=S010120612012000100026\&script $=$ sci_arttext $>$. Accessed: Oct. 10, 2011. doi: 10.1590/S0101-20612012005000020. 